\title{
East Asia's Power Shift: The Flaws and Hazards of the Debate and How to Avoid Them
}

\author{
Linus Hagström and Björn Jerdén
}

\begin{abstract}
The widespread debate on an East Asian power shift is generally based on the crude notion that power and capability are interchangeable. We critique this view and offer the alternative that power is the capacity of actors and discourses to produce effectswhat we call relational and productive power, respectively. We also engage in a reflexive exercise by addressing the productive power of the power-shift debate itself, and emphasize the danger that this debate might enable the kind of realpolitik that it forebodes. KEYWORDS: Japan, power shift, productive power, relational power, rise of China.
\end{abstract}

RECENT DECADES HAVE SEEN WIDE DEBATE IN INTERNATIONAL RELATIONS (IR) and area studies about power relations in East Asia. The understanding that Japan was rising (Vogel 1979; Friedman and Lebard 1991) only started to lose traction as another "power-shift" discourse began to thrive. This time the shift was understood as the result of two phenomena occurring in tandem: an increase in Chinese power, also known as China's "rise," and a decline in the power of the United States and Japan relative to China.

China's rise, the starting point of which is generally taken to be the launch of the reform and opening-up agenda in 1978, is primarily understood to entail enormous increases in China's gross domestic product (GDP), trade flows, and foreign currency reserves, as well as a steady increase in its military spending. Japan's decline, in contrast, largely refers to the economic malaise that began to haunt the country in the early $1990 \mathrm{~s}$ - a combination of slow economic growth, high levels of public debt, chronic deflation, and serious problems related to demography and governance. Also, many US material capabilities have decreased relative to those of China in recent decades. 
Yet the Japan example shows how quickly the debate can turn around, converting yesterday's rising star into tomorrow's biggest loser. Why are power-shift debates generally couched in such confident terms, despite the lack of consideration of how to recognize a power shift, and despite the general lack of interest in theorizing about power? In this article we seek to challenge the conceptual foundations of the power-shift debate, and to reevaluate some of its main assessments, predictions, and policy advice. Crucially, we heed David Baldwin's (2012) call to treat power as the dependent variable rather than the independent one. In our analysis, power shifts do not explain but have to be explained.

The power-shift debate may initially seem to represent radically diverse perspectives and viewpoints, but we begin by arguing that nearly all positions are conditioned on a quite uniform understanding of power. Overall, power is used interchangeably with resources, or capability. We then rehearse some of the criticisms that have been directed against this fundamentally realist concept of power. The bases and instruments of power are not so easily convertible as the power-shift debate implies, and ranking states in terms of overall power is therefore impossible. Another critique is that the realist concept of power is too state-centric, which ironically risks misrepresenting the power relations of states.

Building on this criticism, in the next section we introduce a different concept of power, defining it as the "capacity to produce effects" (Morriss 2002 [1987], 12, emphasis added). Two alternative conceptions stem from this general definition: (1) relational power, according to which the effects can only be evaluated in specific situations, relationships, or contexts; and (2) productive power, according to which effects, including the constitution of the identity and interests of power wielders, are produced through discourses and practices. Some claim that these conceptions rest on conflicting foundations and are therefore incompatible (Berenskoetter 2007). We argue, however, that used in parallel they provide complementary insights into power relations in and beyond East Asia. Drawing on the other articles in this special issue, we highlight a number of necessary distinctions associated with these conceptions and formulate alternative questions about power relations in East Asia. 
In the final section of the article we analyze the power of the power-shift discourse, and the identities and actions that this discourse enables and constrains. We also direct the spotlight on our own alternative understandings of power and discuss how they, too, are entangled in East Asian power relations.

Like the other contributions to this special issue, we do not deny that many indicators currently seem to corroborate the notion that China is rising, that the United States and Japan are declining, and that a power shift is occurring in East Asia. However, a critical review of the literature and a richer and more nuanced understanding of power suggest that much more underlies the question of East Asian power relations than the current debate reveals. By questioning its conceptual foundations and providing alternatives, we hope that this special issue can serve as a much-needed antidote to the complacent terms in which the debate is currently conducted.

\section{The Power-Shift Debate}

Scholars of East Asian international politics have treated a regional power shift as imminent for more than two decades (Betts 1993; Friedberg 1993; Roy 1994). The change in the regional distribution of capabilities is generally considered the independent variable in this debate. Not everyone agrees on the outcome of this power shift, but all agree that it is there. As a result, most contributions to the debate revolve around predictive and prescriptive questions. With regard to predictions, we characterize the debate as consisting of seven ideal-type positions.

Two positions are based on the relatively common assumption that the United States might withdraw some or all of its military presence from East Asia (Betts 1993; Roy 1994; Ikenberry 2004; Samuels 2007; White 2012), yet disagreement exists over how the withdrawal might affect the region. Pessimists argue that since regional peace requires US containment of a number of latent threats (Ikenberry 2004; Shambaugh 2004/05) — primarily Chinese expansionism, North Korean aggression, and Japanese remilitarization-US retrenchment would produce arms races and 
security dilemmas (Friedberg 1993; Roy 1994; Berger 2000; Christensen 2006; Samuels 2007; Goh 2008). The more optimistic scenario is that countries in the region may choose to bandwagon with China, which would then become the new hegemon in a more or less peaceful order (Kang 2007).

If the United States chooses to stay in East Asia, however, several other outcomes are possible. As a result of its growing power, China might aggressively challenge the US-led regional order, while the United States and East Asian countries try to contain the rise of China. The risk of violent conflict then becomes imminent. This expectation is congruent with both offensive realism (Mearsheimer 2010; Layne 2012) and power-transition theory (Tammen and Kugler 2006; Chan 2008).

Rather than containing China, the United States and regional countries might "hedge" against it (Heginbotham and Samuels 2002; Medeiros 2005). China, meanwhile, might attempt to modify the US-led regional order without directly challenging the United States and its allies (Pempel 2010; Schweller and Pu 2011; Chan 2012; Acharya 2013; Breslin 2013). Another way to frame this hypothesis is that the United States and China (as well as Japan, in some accounts) arrive at a stable balance of power (Ross 1999; Waltz 2000; Zhao 2007; White 2012).

Still another position is that the United States, to further stabilize the regional order, increases its political investment in the bilateral and multilateral regional relationships in which it is involved. China continues to integrate into this progressively institutionalized order, and the logics of interdependence and mutual gain help alleviate the potential dangers caused by changes in the region's power distribution (Berger 2000; Ikenberry 2004; Shambaugh 2004/05; Tammen and Kugler 2006; Gurtov 2013). In this scenario, interdependence is even seen as likely to restrict conflict in the tense Sino-Japanese relationship (Manicom and O'Neil 2010). Alternately, China might be socialized into the regional order, leading to the emergence of an East Asian security community (Taniguchi 2004; Qin and Wei 2008).

While all the above scenarios are based on the assumption that power will continue to shift, more skeptical accounts have raised objections. Steve Chan's article in this special issue, for instance, provides a highly qualified assessment. Common argu- 
ments here are that the United States has more power than is often assumed; or that China's economic growth might stop or slow down due to a combination of political, financial, demographic, ethnic, and environmental factors; or both (Chan 2005; 2008; 2010; Shirk 2007; Cox 2011; Beckley 2011/12; Gurtov 2013). In this case, the power shift would slow or even reverse.

In spite of the widespread interest in the power-shift debate among researchers, the conceptual refinement of "power" in most of the works cited above is surprisingly meager. Scholars have typically inferred a power shift more or less based on a perceived change in the distribution of material capability between China, on the one hand, and the United States and Japan, on the other. Moreover, the assumption underlying the power-shift thesis is that a definite causal relation exists between capability and the capacity to produce effects. In short, capability, primarily material capability, is power. Economic capability, moreover, is destined to be translated into military power, and economic and military power into political and diplomatic clout. The premise that power is highly fungible or convertible leads almost inevitably to the conclusion that Chinese power will grow in more or less all areas.

This understanding of power stems from the fundamental tenets of realism. The finding that realist ideas steer the debate is not very surprising, since the study of power in IR has largely taken place within the confines of the realist paradigm (Schmidt 2007). For realists, power typically serves as the independent variable in explanations of both system-level occurrences, such as war and peace (Waltz 1979), and unit-level ones, such as foreign policies (Rose 1998). In order to use power as the independent variable, it must be recognizable and measurable, which results in the understanding that capabilities are synonymous with, or correspond to, power-an approach adopted by nearly all realists (Hagström 2005a; Schmidt 2007) that is known as "elements of national power" (Baldwin 2012, 274). That approach, moreover, has spilled over into theories and analytical approaches not necessarily associated with realism, and which do not use power as an independent variable.

In sum, the literature has assumed the existence of a power shift, with the pretense that the only relevant scholarly discord 
concerns how the power shift will affect the regional order and how states - in particular, the United States - should deal with such changes. This preoccupation with assessing competing outcomes has typically led to a fairly cursory treatment of the more primary questions of whether - and, if so, how - a power shift is taking place.

\section{A Conceptual Critique of the Power-Shift Debate}

The realist concept of power has several problems. To begin with, associating economic resources with discrete state actors is at best complex and at worst theoretically dubious. In this special issue, Chengxin Pan unpacks the image of monolithic Chinese economic power. He emphasizes how dependent Chinese capability is on capital and technology emanating from outside of China and how entangled it is with global production networks. The same is clearly the case with ideational and normative power. The normative Western order, which in Alexander Bukh's account is constraining Japanese soft power, might work to the benefit of the United States, but that does not mean that the US government controls this order, or even that it was instrumental in its creation. In fact, many of the order's features arguably precede the rise of the United States to global dominance. Therefore, much of the power in the international system cannot be neatly boxed into discrete and unitary state actors, and the power relations of states are not always the most meaningful objects for power analysis.

Having said that, the power-shift debate is about the rise and fall of national power, and addressing this debate means focusing on states as the wielders of power. The degree of correspondence between power and states also varies between contexts; for instance, there seem to be fairly close fits between states and power in the military and diplomatic fields.

\section{Power as National Capabilities}

As noted above, the power-shift debate treats the changing distribution of capabilities between states as the independent variable, 
which is then used to explain and predict the structure of regional interactions. Scholars do this in three ways, two of which are untenable and one of which is arguably pointless. These objections are not new; in fact, some stretch back well over half a century. The fact that they have been conspicuously absent from the power-shift debate, however, makes rehearsing them worthwhile.

The first approach asserts that military power is the ultimate means of influence in international politics (Rothgeb 1994). However, it is unclear how a single index could be used to compare countries' military power (Baldwin 2012). How can disparate indicators, such as the size of standing forces, the number of nuclear weapons, or effectiveness in nonconventional warfare, be merged into a measure of war-fighting capacity?

The second approach recognizes the existence of distinct bases and instruments of power but sees them as essentially convertible. Christopher Layne, for instance, writes, "There is a critical linkage between a great power's military and economic standing, on the one hand, and its prestige, soft power, and agenda-setting capacity, on the other" $(2012,22)$. Power is like money; one form of power can be converted into other forms without significant translation costs. Critics, however, argue that a useful instrument in one context is not necessarily useful in another (Baldwin 1989; 2012). Chan's article in this special issue reminds us that policy capacity and incentives have an important bearing on whether and how capabilities translate into power. Despite the conspicuous growth of the Chinese military budget relative to Japan's, for instance, Beijing has not gotten its way in the bilateral territorial dispute over the Senkaku/Diaoyu Islands (Hagström 2012). As Karl Gustafsson shows in this special issue, the Chinese government's ability to influence Japan through the use of narratives related to the past actually seems to have decreased in recent years. Moreover, the conspicuous diffusion of Japanese culture in China and Chinese culture in Japan are often portrayed as soft-power resources (Otmazgin 2008; Heng 2010), but in neither case has the attraction to cultural artifacts translated into a more general sense of attraction to the other.

The third approach identifies the existence of distinct bases and instruments of power, recognizes that they are not easily con- 
vertible, but nonetheless maintains the value of ranking states in terms of overall power. Yan Xuetong, for example, constructs a power index, while arguing that political, economic, and military power components are all vital to state power and "cannot be converted unconditionally" $(2006,17)$. Comparing the comprehensive power of states involves methodological anarchy, and Chan (2005) demonstrates how commonly used power indexes yield completely different results-some showing that a global shift is imminent, others that it is quite far away. However, this approach arguably has an even more fundamental problem. If we recognize that power is issue-specific and not very convertible, what is the value of ranking countries in an overall power index? How can we possibly ascribe causal powers to such an independent variable? Furthermore, if we do not plan to use the index as an independent variable, what is the point of constructing it in the first place? Such concerns have led Baldwin (2012) to argue that this kind of analytical exercise is essentially meaningless.

To sum up these criticisms, in the words of Baldwin, "There is no 'general purpose' currency that can be used to exercise political power of generalized scope and domain" $(1989,30)$. Thus, we cannot identify a "single monolithic international "power structure" in international politics (Baldwin 1989, 166). Similarly, no power resource is fundamental in East Asia, and consequently no single monolithic East Asian power structure exists.

\section{An Alternative Conceptual Approach to Power Relations in East Asia}

\section{Relational Concepts of Power}

The main alternative to the property concept is one that focuses on the "capacity to produce effects" (Morriss 2002 [1987], 12), in which context-specific studies of effects take center stage. Under this broad umbrella we find the relational and productive conceptions of power, which differ in the relative explanatory weight they give to actors and discourses. 
The relational concept, to begin with, is characterized by an interest in how and when actors manage to produce effects on each other. Since actors do not have the capacity to produce the same effects at all times and in all places, the relational concept also requires awareness of the specific context of $A$ 's power over $B$. Employing this concept completely changes the parameters of the debate. Power shift in East Asia becomes a dependent variable-something that needs to be established though empirical investigation.

The "faces of power" debate has been central to the development of the relational concept. Representing the first face, Robert Dahl defines power as "a successful attempt by $A$ to get $a$ to do something he would not otherwise do" (Dahl 1957, 204). Dahl focuses on who succeeds in overt decisionmaking in observable disagreements or conflicts concerning vital issues. Key questions include: Who participates? Who gains? Who prevails? Actors who, against the will of others, successfully initiate, oppose, veto, or alter alternatives in concrete agenda setting or decisionmaking are seen as powerful. Paul O'Shea's article in this special issue exemplifies this kind of power relation by showing how the US government managed to contain Prime Minister Hatoyama Yukio's attempt in 2009-2010 to renegotiate the accord on the relocation of the Futenma US Marine Corps Air Station in Okinawa.

According to the second face, power is also exercised by determining which issues and people are allowed into the debate. Hence, the focus is on nondecisions, covert conflicts, potential issues, and agenda setting (Bachrach and Baratz 1962). It is possible to expand on O'Shea's analysis by arguing that the Democratic Party of Japan's (DPJ) compliance with the US stance on Futenma after Hatoyama's resignation in 2010, as well as the DPJ's continued neglect of the concerns of many Okinawans, could be understood as stemming from the DPJ's fear that it would damage US trust in Japan or even cause the alliance to break apart if it continued to pursue the issue.

The gist of Steven Lukes's (2005 [1974]) renowned third face is that the other faces are biased toward the political systems that they set out to investigate, thereby neglecting groups and issues that are completely shut out of politics. Power, according to 
Lukes, can be exercised without an explicit conflict of interest between $A$ and $B$. $A$ can exert power over $B$ by means of control, manipulation, and authority, even without $B$ or $A$ being aware of that relationship. In this kind of power relationship, conflicts become latent.

To illustrate, let us again extrapolate from O'Shea's argument. There is enduring resistance in Japan to some manifestations of the Japan-US alliance, as demonstrated by the DPJ's successful politicization of the issue in its 2009 election campaign. Nonetheless, conflicts over the alliance relationship per se, which were quite overt during the Cold War, are now relegated to near obscurity. Even the Hatoyama government, which was often portrayed as anti-United States, emphasized in its election manifesto that the alliance was the "foundation" (kiban) of Japanese diplomacy (Minshutō 2009, 22).

The faces-of-power debate was quite progressive in that each new face enabled scholars to recognize the existence of increasingly subtle but fundamental ways of exercising power. Some understood the debate to ultimately hinge on how to understand the involvement of agents and structures in the operation of power, portraying the third face as a structuralist account (Gill and Law 1989; Hindess 1996). Lukes, however, has made clear arguments in favor of an agency concept of power (Lukes 2005 [1974]). Baldwin $(1985 ; 1989 ; 2012)$ is the pioneer in attempting to adapt to IR arguments from the faces debate, but arguably his work does not extend beyond the first face. Drawing on the third face, moreover, Linus Hagström (2005b) argues that the relational concept is particularly well suited to foreign policy analysis.

\section{Toward an Understanding of Productive Power}

While the first two faces make power conditional on $A$ 's intentionality, one of Lukes's main contributions is the introduction of a nonintentional element of agency power. Yet the lack of access to other minds makes it difficult to distinguish between intentional and nonintentional effects. Much human behavior is also nonintentional or habitual (Hopf 2010). As Stefano Guzzini suggests, therefore, "the analytical chain" should start "not from 
agent's intentions but from basic actions" (1993, 459). Hence, whether the US government intended to bring about Hatoyama's resignation in 2010 is not relevant, although arguably it did (Jerdén 2012). The point is rather that the US government's actions could be construed as producing this result.

Another example revolves around the effects of the arguably flawed narrative depicting China in 2009-2010 as increasingly "assertive" (Johnston 2013; Jerdén 2014). The fear of a suddenly more confrontational China became one of the main reasons behind the US "rebalancing" to Asia. Again, whether this "assertive China narrative" was intentionally constructed and spread is beside the point; it produced effects and was thus a power exercise (Jerdén 2014).

To account for narrative power and other attempts to shape the wants of other actors through the transmission of ideas, norms, and symbols, Hagström (2005b) introduced the concept of "ideational statecraft." This concept is similar to Ian Manners's notion of normative power, or the "ability to define what passes for 'normal' in world politics" $(2002,236)$ — and to Dirk Nabers's notion of "leadership," or "an actor's ability to present his own particular worldview as compatible with the communal aims" (2010, 938). It also seems closely related to Joseph Nye's popular idea of soft power- "the ability to shape the preferences of others" through attraction, enticement, or cooption $(2004,5)$ although Nye professes kinship mostly with the second face, and in his empirical work tends to revert back to the counting of cultural artifacts through which attraction may or may not occur (Nye 2000; 2004; Gallarotti 2011).

While Baldwin's Dahl-inspired approach to power is causal, Hagström, Manners, and Nabers are more interested in constitutive effects (see also Barnett and Duvall 2005; Berenskoetter 2007). A causal effect could be defined as $A$ producing effects that go against $B$ 's professed interests or preferences, while a constitutive effect denotes the very production of $B$ 's interests or identity. In this special issue, Gustafsson and O'Shea operate with a similar concept of power. Gustafsson shows how Beijing and Tokyo have tried to shape and reshape each other's understanding of history, as well as the understandings of third parties. 
O'Shea demonstrates how US "scholar-officials" constructed the social reality of a "crisis" in the Japan-US alliance, which was largely accepted by the Japanese media, and in turn shaped how many Japanese viewed Hatoyama's policies. Soft power to Alexander Bukh is also exercised by agents but is at the same time a reflection of discursively constructed national identities, which, to a large degree, are shaped by international ideational structures.

To enable analysis of how $A$ shapes $B$ 's interests, Lukes posits that actors have "real interests." However, real interests cannot be assumed to exist prior to constitutive power relations. Indeed, even autonomy and economic well-being could be viewed as culture-specific. In a similar vein, Bukh demonstrates that the Japanese government heavily emphasizes liberal democracy, freedom, human rights, and the market economy in its cultural diplomacy. Values of this kind could, of course, be construed as universal, beyond power relations, and hence in Japan's real interests. However, Bukh demonstrates that these originally Western values in fact serve to constrain Japanese agency. Moreover, even if one accepts that it is possible to identify an individual's real interests, the difficulty of doing so multiplies with corporate actors such as states. There is no convincing account of what constitutes real state interests, except perhaps the prevention of total annihilation.

Lukes has also suggested that "I will have more (overall) power than you if I can bring about outcomes that are more 'significant' than those you can bring about" $(2007,87)$. Once again, however, it seems impossible to distinguish between more and less significant effects without imposing a specific concept of interests. Seemingly pacific effects might also legitimize or produce the conditions for or possibility of other, more bellicose effects. Janice Bially Mattern writes that soft power, "however unappealing, is normatively more appealing than the power politics of war, empire, and physical conquest" $(2007,117)$. However, she misses the point that even such phenomena can be produced and legitimized through the diffusion of, and attraction to, certain ideas, values, norms, or practices. This was famously demonstrated by Japan's "Janus-faced" socialization into Western international society in the late nineteenth century, which precisely 
enabled Bially Mattern's "war, empire, and physical conquest" (Suzuki 2005). Western liberal values in Bukh, historical narratives in Gustafsson, and an idea of what constitutes a practical and realistic security policy in O'Shea all enable some actions and constrain others.

Nonetheless, is it reasonable to attribute the production of, in Manners's (2002) words, "what passes for "normal" or, for that matter, "practical" and "realistic" in world politics, to the workings of actors alone? Moreover, can processes of socialization be exhaustively understood from the point of view of interacting agents - as Pang (2004) and Pu (2012) seemingly argue? Many scholars would say no, which is why Peter Digeser introduced a "fourth face of power" that builds largely on Michel Foucault's social theory. While most of the power debate operates with $A$ s and $B \mathrm{~s}$, the fourth face "does not take as presupposed the subjects ... of the three other faces" (Digeser 1992, 980). This is the view that power circulates in and permeates practices and discourses, (re)producing knowledge about the world and social subjects alike. Knowledge and agents are thus both the products and the vehicles of power (Digeser 1992; Foucault 2000). Barnett and Duvall refer to this impersonal power as "productive power" (2005, 55-57), and that is the term we employ here. Guzzini calls it "governance," defining it as "the capacity of intersubjective practices to effect" $(1993,471)$. Thus far, this concept has been adopted in IR research on governance-for example, to analyze governmentality (Sending and Neumann 2006) and power diffusion (Guzzini and Neumann 2012). However, productive power also shapes the conditions for interactions and outcomes that are more associated with Realpolitik.

In Bukh's article, productive power is exemplified by the dissemination and entrenchment of discourses of liberal democracy, freedom, human rights, and the market economy. Productive power also occupies a central place in Pan's call for a more multifaceted and critical power analysis. For instance, Pan argues that the discourse on Chinese power is a "key source" of its power. In this view, Chinese power is partly "imagined" (Breslin 2009, 835 ). However, one could hypothesize that such imaginations, if widespread, might constrain rather than enable Chinese power. 
Indeed, while Gustafsson argues that China's discursive power over Japan is smaller than expected, the discursive battles between the two countries are one important arena where "China's rise" emerges as a discursive phenomenon and China is described as "aggressive" and "assertive." This in turn enhances the concern around the world that China is a threat, and makes balancing behavior seem natural and normal. States are not only attracted to wealth and military force (Kearn 2011). Discourses that define international "status," "recognition," and "normality" also heavily condition states' international postures (Deng 2008; Suzuki 2008; Hagström 2014). These discourses are not controlled by identifiable actors; in fact, their circulation in the international system precedes the emergence of many current state actors.

\section{Assessing Power as the Dependent Variable}

In sum, at one level our concept of power focuses on the causal and constitutive effects that actors produce in their relations with each other. At another level it employs the notion of productive power to analyze the configuration of actors and the conditions for their interaction. This understanding of power, which is at the same time agential and intersubjective, falls squarely within the constructivist fold of IR theory (Guzzini 2007). Relational power and productive power could be interpreted as resting on different foundations and therefore incompatible. However, just as ontologically more fundamental physics can coexist with chemistry and biology in the natural sciences, we argue that it is possible to engage at the same time with the ontologically more fundamental question of how actors are intersubjectively constituted, and the more applied question of how emergent actors behave.

How can this understanding contribute to the debate on East Asian power relations? Since we treat power as a dependent variable, it cannot be deployed to explain "international outcomes such as wars, alliances, and the operation of the balance of power," as in neorealism (Schmidt 2007, 54). As William Wohlforth correctly argues, if power is defined as certain outcomes in the relationship between $A$ and $B$, it is "a dubious ana- 
lytical exercise" to use "power to explain those outcomes" (1993, 4). The power-shift literature, however, typically does not address the macro level, but often looks instead at more isolated bilateral or regional cases related to specific issue areas. Thus, many participants in the debate could benefit from focusing on power as a dependent variable.

Based on our concept of power, two major sets of questions should be addressed to investigate the question of power shift. The first set investigates the way the actors are constituted: What discourses and practices are central to how China, Japan, and the United States are constituted as actors? Have these discourses and practices changed over time? If so, how? How do these discourses and practices enable and constrain action? What actions become conceivable, communicable, and coercive as such discourses and practices become entrenched? The other set brackets the constitution of state actors to inquire about their interactions: What kinds of military, economic, diplomatic, or ideational effects on state actors - causal and constitutive - can be associated with other state actors? Has the distribution among these effects changed over time? If so, how? How appropriate is it to associate effects with state actors to begin with? Conversely, what is the role of nonstate actors in the equation?

\section{The Power of the Power-Shift Discourse}

One discourse that is arguably central to how China, Japan, and the United States are currently constituted is the power-shift discourse itself. The entrenchment of this discourse in and beyond academia is tightly entwined with power relations in East Asia. The notion that power and knowledge are intrinsically linked, or "co-constituted," is the gist of Foucault's concept of power. To Lukes, knowledge of their "real interests" can emancipate the victims of power, but to Foucault there is no knowledge beyond power relations, just as "there is no power relation without a field of knowledge" (Digeser 1992, 986).

Scholars have drawn on this idea to remind each other that "the pursuit and production of knowledge itself creates norms and 
standards of behavior" (Digeser 1992, 991). Hence, knowledge production, including scholarship, plays an important role in promoting collective understandings in which certain ideas are seen as "legitimate" and others as "outlandish." Knowledge production thus becomes deeply entangled in power relations. In IR, constructivists and poststructuralists have consequently attacked realist discourse, particularly neorealism, as a "power practice" (Guzzini 1993, 465). Since the power-shift discourse rests on a particularly realist - and, according to L. H. M. Ling (2013), Westphalian-concept of power, this criticism is clearly of relevance here.

Once we acknowledge that academic concepts and analyses can have constitutive effects, we need to analyze their performative role. This means addressing the "double hermeneutic"- the way " findings' of the social sciences very often enter constitutively into the world they describe" (Giddens 1987, 20) - and reflecting on what our interpretations might "do" (Guzzini 2007, $23)$. It is not necessary to accept social constructivism to recognize that the practice of social science is interlinked with power relations outside of academia. Far from scholarly navel-gazing, a reflexive attitude is arguably a necessary ingredient of any rigorous social science practice (Bourdieu and Wacquant 1992).

Hence, since the power-shift discourse is not simply a descriptive account of an independent reality but is destined to be constitutive of that reality, it is essential to explore its power. Thomas Diez (2005) makes a similar investigation into the power of the concept of "normative power Europe" (NPE). He finds that NPE constructs a benevolent and peaceful identity for Europe, but also that its alleged peacefulness is contrasted with and therefore dependent on an idea of what Europe is not - an outside consisting of "challenging threats" $(2005,636)$. The double hermeneutic twist is that the coining of the originally academic NPE concept has become an important instance of Europe's "normative power."

Diez (2013), however, seems to take for granted the distinction between post-Westphalian normative powers, which engage in a struggle over the definition of "normality" in world politics, and Westphalian great powers, which engage in war, empire building, and physical conquest. "Great powers," however, are 
also the products of normative, discursive pressures, and they reproduce ideas of what is "normal" great-power behavior. Much of the power-shift discourse reproduces the same familiar self/ other dichotomy as the NPE literature. Here, the other is a rising and potentially threatening China, while the self is a weak but inherently righteous United States/West/Japan.

Pan argues that the "China threat discourse" is "always intrinsically linked to how US policymakers/mainstream China specialists see themselves (as representatives of the indispensable, security-conscious nation, for example)" (2004, 306). Hagström demonstrates how the discourse on Japan's "abnormality" and "weakness" reproduces a standard of "normality" in world politics that is centered on the ability to go to war. Postwar Japan is socially constructed as deviant from this norm and thus as a threat to itself. This discourse, which emerges in both Japanese and Western academia and in Japanese political debate, legitimizes a road map for a more "realistic," "active," "responsible," and "normal" Japan (Hagström 2014).

The power of the power-shift discourse does not stop at the production of identities and standards. The point is that identities and standards produce effects. Pan illustrates this by showing how the Taiwan Strait Crisis in 1995-1996 was often understood as "further objective proof of the long-suspected 'China threat," but few acknowledged that "the 'China threat' discourse itself had played a constitutive role in the lead-up to that crisis" (2004, 323, 320). Moreover, standards in Japan's "normalization" discourse have enabled Realpolitik changes in its foreign security policy. Chinese vigilance vis-à-vis Japan and the United States might also be interpreted as discursive phenomena-the theme of national reinvigoration is a product of the lingering notion that China has been continually humiliated and victimized by the great powers since the nineteenth century. As these examples illustrate, the ultimate power of discourse is the production of self-fulfilling prophecies. When self-fulfilling prophecies occur on both sides of a dyad, we might end up with a socially generated security dilemma (Johnston 2004).

Much research has warned of self-fulfilling prophecies in the East Asian context. Some observers suggest that US or Japanese 
discourses about China might produce policies of containment, Japanese "normalization" and "remilitarization," and US "rebalancing" toward East Asia (Pan 2004; 2012; Hagström 2012; Turner 2014a; 2014b). Nonetheless, Japan and the United States have not yet embarked on containing China. Instead, both countries have on the whole accommodated China's rise (Christensen 2006; Jerdén and Hagström 2012). In a similar manner, perceived increases in bellicose or nationalistic representations in Chinese discourses led some observers to jump to the mistaken conclusion that this had already resulted in a more assertive Chinese foreign policy (Jerdén 2014). As important as it is to remain vigilant against the emergence of socially constructed security dilemmas, we need to bear in mind that there is no deterministic connection between discourse and policy_-just an enabling one. Dominant discourses create propensities for action but do not make any action inevitable. More empirically informed theorizing is needed to address the questions of how, when, and why discourses make some actions politically conceivable, easy to communicate, and sometimes even coercive (Holland 2013).

Reflecting on the possible power exercised through the alternative approaches introduced in this special issue is also necessary. In this article we raise analytical and normative concerns about the ideas of a more "powerful" and "threatening" China, a "weak" Japan, and a "declining" United States. We argue that such representations risk offsetting balancing policies and a security dilemma in East Asia, in line with the self-fulfilling prophecy logic discussed above. These arguments clearly belong to another site of discursive power production. That we have not seen any obvious balancing policies in East Asia thus far might arguably be interpreted as one of its effects.

In fact, our critique of the power-shift debate might itself be criticized as denying or playing down Chinese power, which could have two effects: (1) China appears less powerful and thus less threatening, which allows it to arm itself with impunity and behave aggressively; and (2) the Chinese government can ignore calls to take on more international responsibilities with reference to the limited scope of its power. As William Callahan points out, attempts to counter the "China threat theory" within China 
often "refute 'Chinese' threats as a way of facilitating the production of an American threat, a Japan threat, an India threat, and so on" $(2005,711)$. Adopting a nonintentional power concept allows us to see how even critical scholars, inside and outside China, who profess no interest in exaggerating threats against China but rather "seek to deconstruct the discourse of "threat," might play a role in accelerating this process (Callahan $2005,711)$. In other words, intentional attempts to prevent the emergence of a self-fulfilling prophecy may actually play an unintentional part in creating one.

\section{Conclusion}

The power-shift debate is rich and varied, theoretically and empirically, but the central concept of the discourse-power-remains severely undertheorized. Most of the literature typically sticks with a property concept of power, equating it with capabilities. This concept is linked to a number of well-known measurement and conversion problems. Rather than adopting alternative understandings of power, such as those discussed in this article-many of which have a long pedigree in the theoretically oriented IR literature-most scholars and other observers continue to understand China's rise and power shift in terms of capabilities. Widespread expectations in the 1970s and 1980s that Japan would overtake the United States as the predominant actor in the international system were based on the same flawed concept of power.

Why do analysts continue to stick with the property concept? We believe that the question of the power in the power-shift discourse must enter the analysis at this point. Building on the idea of productive power, we argue that one reason for the diffusion and entrenchment of the power-shift discourse is its central role in identity constructions in the United States, China, Japan, and elsewhere-today as much as in the past. Identity is one plausible way to understand the link between productive power and the flawed focus on power as capability.

The aim of this special issue is not to replace the current power-shift debate with a new grand narrative of what is going on 
in and beyond East Asia, but rather to challenge and denaturalize it through a series of critiques and analyses of a more limited scope. We do not argue that all observations in the debate are unreasonable. Our objection is that the debate is too one-sided. That certain Chinese capabilities are increasing relative to those of the United States and Japan, or that China exercises more power than before in some issue areas or contexts, does not sufficiently motivate the stipulation of a power shift, or the kneejerk interpretation of any regional interaction as having been caused by such a shift.

Having said that, the empirical findings in this special issue provide grounds for caution regarding the idea that China's power is growing across the board, or that Japan and the United States are becoming increasingly powerless in East Asia. Chan lays bare the inherent weaknesses in the power calculations on which the idea of China's rise is based. Pan shows that Chinese economic power is much less Chinese than commonly assumed. Gustafsson suggests that China's discursive power of the past has decreased. O'Shea and Bukh demonstrate that US power lingers on, over Japan and in East Asia as a whole.

\section{Notes}

Linus Hagström is associate professor of political science and senior research fellow at the Swedish Institute of International Affairs. He is also a research fellow at the Royal Swedish Academy of Letters, History, and Antiquities, supported by a grant from the Knut and Alice Wallenberg Foundation. Hagström's research revolves around questions of power and identity in East Asian international relations. He is the author of Japan's China Policy: A Relational Power Analysis (2005). He can be reached at linus.hagstrom@ui.se. Björn Jerdén is a PhD candidate in the Department of Political Science, Stockholm University, and research associate at the Swedish Institute of International Affairs. His dissertation assesses how and why China's rise has affected international politics in East Asia. He can be reached at bjorn.jerden@ui.se.

We would like to thank Steve Chan, Mel Gurtov, Karl Gustafsson, Chengxin Pan, and Oliver Turner for their helpful comments on earlier versions of this article. We would also like to express our sincere gratitude to the reviewers for this special issue. 


\section{References}

Acharya, Amitav. 2013. "Power Shift or Paradigm Shift? China's Rise and Asia's Emerging Security Order.” International Studies Quarterly, vol. 58, no. 1 (March), pp. 158-173.

Bachrach, Peter, and Morton S. Baratz. 1962. "Two Faces of Power." American Political Science Review, vol. 56, no. 4 (December), pp. 947-952.

Baldwin, David A. 1985. Economic Statecraft. Princeton, NJ: Princeton University Press.

1989. Paradoxes of Power. New York: Basil Blackwell.

- 2012. "Power and International Relations." In Walter Carlsnaes, Thomas Risse, and Beth Simmons, eds., Handbook of International Relations. London: SAGE Publications, pp. 273-297.

Barnett, Michael, and Raymond Duvall. 2005. "Power in International Politics." International Organization, vol. 59, no. 1 (Winter), pp. 39-75.

Beckley, Michael. 2011/12. "China's Century? Why America's Edge Will Endure." International Security, vol. 36, no. 3 (Winter), pp. 41-78.

Berenskoetter, Felix. 2007. "Thinking About Power." In Felix Berenskoetter and M. J. Williams, eds., Power in World Politics. London: Routledge, pp. 1-22.

Berger, Thomas. 2000. "Set for Stability? Prospects for Conflict and Cooperation in East Asia." Review of International Studies, vol. 26, no. 3 (July), pp. 405-428.

Betts, Richard K. 1993. "Wealth, Power, and Instability: East Asia and the United States After the Cold War.” International Security, vol. 18, no. 3 (Winter), pp. 34-77.

Bourdieu, Pierre, and Loïc J. D. Wacquant. 1992. An Invitation to Reflexive Sociology. Chicago: University of Chicago Press.

Breslin, Shaun. 2009. "Understanding China's Regional Rise: Interpretations, Identities, and Implications." International Affairs, vol. 85, no. 4 (July), pp. 817-835.

- 2013. "China and the Global Order: Signalling Threat or Friendship?” International Affairs, vol. 89, no. 3 (May), pp. 615-634.

Callahan, William A. 2005. "Forum: The Rise of China. How to Understand China: The Dangers and Opportunities of Being a Rising Power." Review of International Studies, vol. 31, no. 4 (October), pp. 701-714.

Chan, Steve. 2005. "Is There a Power Transition Between the US and China? The Different Faces of National Power." Asian Survey, vol. 45, no. 5 (September/October), pp. 687-701.

- 2008. China, the US, and the Power-Transition Theory: A Critique. London: Routledge.

- 2010. "An Odd Thing Happened on the Way to Balancing: East Asian States' Reactions to China's Rise.” International Studies Review, vol. 12 , no. 3 (September), pp. 387-412. 
2012. Looking for Balance: China, the United States, and Power Balancing in East Asia. Stanford, CA: Stanford University Press.

Christensen, Thomas J. 2006. "Fostering Stability or Creating a Monster? The Rise of China and US Policy Toward East Asia." International Security, vol. 31, no. 1 (Summer), pp. 81-126.

Cox, Michael. 2011. "Power Shift and the Death of the West? Not Yet!" European Political Science, vol. 10, no. 3 (September), pp. 416-424.

Dahl, Robert. 1957. "The Concept of Power." Behavioral Science, vol. 2, no. 3 (June), pp. 201-215.

Deng, Yong. 2008. China's Struggle for Status: The Realignment of International Relations. New York: Cambridge University Press.

Diez, Thomas. 2005. "Constructing the Self and Changing Others: Reconsidering 'Normative Power Europe.'” Millennium - Journal of International Studies, vol. 33, no. 3 (June), pp. 613-636.

- 2013. "Normative Power as Hegemony." Cooperation and Conflict, vol. 48, no. 2 (June), pp. 194-210.

Digeser, Peter. 1992. "Fourth Face of Power." Journal of Politics, vol. 54, no. 4 (November), pp. 977-1007.

Foucault, Michel. 2000. “The Subject and Power.” In James D. Faubion, ed., Power. New York: New Press, pp. 326-348.

Friedberg, Aaron L. 1993. "Ripe for Rivalry: Prospects for Peace in a Multipolar Asia." International Security, vol. 18, no. 3 (Winter), pp. 5-33.

Friedman, George, and Meredith Lebard. 1991. The Coming War with Japan. New York: St. Martin's Press.

Gallarotti, Giulio M. 2011. "Soft Power: What It Is, Why It's Important, and the Conditions for Its Effective Use." Journal of Political Power, vol. 4, no. 1 (April), pp. 25-47.

Giddens, Anthony. 1987. Social Theory and Modern Sociology. Stanford, CA: Stanford University Press.

Gill, Stephen, and David Law. 1989. "Global Hegemony and the Structural Power of Capital." International Studies Quarterly, vol. 33, no. 4 (December), pp. 475-499.

Goh, Evelyn. 2008. "Hierarchy and the Role of the United States in the East Asian Security Order." International Relations of the Asia-Pacific, vol. 8, no. 3 (September), pp. 353-377.

Gurtov, Mel. 2013. Will This Be China's Century? A Skeptic's View. Boulder, CO: Lynne Rienner.

Guzzini, Stefano. 1993. "Structural Power: The Limits of Neorealist Power Analysis." International Organization, vol. 47, no. 3 (Summer), pp. 443-478.

- 2007. "The Concept of Power: A Constructivist Analysis." In Felix Berenskoetter and M. J. Williams, eds., Power in World Politics. London: Routledge, pp. 23-42.

Guzzini, Stefano, and Iver B. Neumann, eds. 2012. The Diffusion of Power in Global Governance: International Political Economy Meets Foucault. Houndmills, UK: Palgrave Macmillan.

Hagström, Linus. 2005a. 'Ubiquity of 'Power' and the Advantage of Termi- 
nological Pluralism: Japan's Foreign Policy Discourse.” Japanese Journal of Political Science, vol. 6, no. 2 (August), pp. 145-164.

. 2005b. "Relational Power for Foreign Policy Analysis: Issues in Japan's China Policy." European Journal of International Relations, vol. 11, no. 3 (September), pp. 395-430.

—. 2012. "Power Shift' in East Asia? A Critical Reappraisal of Narratives on the Diaoyu/Senkaku Islands Incident in 2010." Chinese Journal of International Politics, vol. 5, no. 3 (Autumn), pp. 267-297.

_ 2014. "The 'Abnormal' State: Identity, Norm/Exception, and Japan." European Journal of International Relations, forthcoming.

Heginbotham, Eric, and Richard J. Samuels. 2002. "Japan's Dual Hedge." Foreign Affairs, vol. 81, no. 5 (September/October), pp. 110-121.

Heng, Yee-Kuang. 2010. "Mirror, Mirror on the Wall, Who Is the Softest of Them All? Evaluating Japanese and Chinese Strategies in the 'Soft' Power Competition Era." International Relations of the Asia-Pacific, vol. 10, no. 2 (May), pp. 275-304.

Hindess, Barry. 1996. Discourses of Power: From Hobbes to Foucault. Oxford: Blackwell.

Holland, Jack. 2013. "Foreign Policy and Political Possibility." European Journal of International Relations, vol. 19, no. 1 (March), pp. 49-68.

Hopf, Ted. 2010. "The Logic of Habit in International Relations." European Journal of International Relations, vol. 16, no. 4 (December), pp. 539561.

Ikenberry, G. John. 2004. "American Hegemony and East Asian Order." Australian Journal of International Affairs, vol. 58, no. 3 (September), pp. 353-367.

Jerdén, Björn. 2012. "Dold diplomati" [Hidden diplomacy]. Internationella studier, no. 3, pp. 54-55.

_ 2014. "The Assertive China Narrative: Why It Is Wrong and How So Many Still Bought into It." Chinese Journal of International Politics, vol. 7 , no. 1 (Spring), pp. 47-88.

Jerdén, Björn, and Linus Hagström. 2012. "Rethinking Japan’s China Policy: Japan as an Accommodator in the Rise of China, 1978-2011." Journal of East Asian Studies, vol. 12, no. 2 (May-August), pp. 215-250.

Johnston, Alastair Iain. 2004. "Beijing's Security Behavior in the AsiaPacific: Is China a Dissatisfied Power?" In J. J. Suh, Peter J. Katzenstein, and Allen Carlson, eds., Rethinking Security in East Asia: Identity, Power, and Efficiency. Stanford, CA: Stanford University Press, pp. 34-96.

- 2013. "How New and Assertive Is China's New Assertiveness?" International Security, vol. 37, no. 4 (Spring), pp. 7-48.

Kang, David C. 2007. China Rising: Peace, Power, and Order in East Asia. New York: Columbia University Press.

Kearn, David W. 2011. "The Hard Truths About Soft Power." Journal of Political Power, vol. 4, no. 1 (April), pp. 65-85.

Layne, Christopher. 2012. "The Global Power Shift from West to East." National Interest, no. 119 (June), pp. 21-32. 
Ling, L. H. M. 2013. "Worlds Beyond Westphalia: Daoist Dialectics and the 'China Threat."' Review of International Studies, vol. 39, no. 3 (July), pp. 549-568.

Lukes, Steven. 2005 [1974]. Power: A Radical View. 2nd ed. Houndmills, UK: Palgrave Macmillan.

- 2007. "Power and the Battle for Hearts and Minds: On the Bluntness of Soft Power." In Felix Berenskoetter and M. J. Williams, eds., Power in World Politics. London: Routledge, pp. 83-97.

Manicom, James, and Andrew O’Neil. 2010. "Accommodation, Realignment, or Business as Usual? Australia's Response to a Rising China." Pacific Review, vol. 23, no. 1 (March), pp. 23-44.

Manners, Ian. 2002. "Normative Power Europe: A Contradiction in Terms?" Journal of Common Market Studies, vol. 40, no. 2 (June), pp. 235-258.

Mattern, Janice Bially. 2007. "Why 'Soft Power' Isn't So Soft: Representational Force and Attraction in World Politics." In Felix Berenskoetter and M. J. Williams, eds., Power in World Politics. London: Routledge, pp. 98-119.

Mearsheimer, John J. 2010. "The Gathering Storm: China's Challenge to US Power in Asia." Chinese Journal of International Politics, vol. 3, no. 4 (Winter), pp. 381-396.

Medeiros, Evan S. 2005. "Strategic Hedging and the Future of Asia-Pacific Stability." Washington Quarterly, vol. 29, no. 1 (Winter), pp. 145-167.

Minshutō [Democratic Party of Japan]. 2009. "Seiken kōtai: Minshutō no seiken seisaku manifesto" [Change of government: The DPJ government's policy manifesto]. Tokyo: Minshutō.

Morriss, Peter. 2002 [1987]. Power: A Philosophical Analysis. Manchester, UK: Manchester University Press.

Nabers, Dirk. 2010. "Power, Leadership, and Hegemony in International Politics: The Case of East Asia." Review of International Studies, vol. 36, no. 4 (November), pp. 931-949.

Nye, Joseph S., Jr. 2000. “Asia’s First Globalizer.” Washington Quarterly, vol. 23, no. 4 (Winter), pp. 119-124.

- 2004. Soft Power: The Means to Success in World Politics. New York: Public Affairs.

Otmazgin, Nissim Kadosh. 2008. "Contesting Soft Power: Japanese Popular Culture in East and Southeast Asia." International Relations of the Asia-Pacific, vol. 8, no. 1 (January), pp. 73-101.

Pan, Chengxin. 2004. "The 'China Threat' in American Self-Imagination: The Discursive Construction of Other as Power Politics." Alternatives: Global, Local, Political, vol. 29, no. 3, pp. 305-331.

- 2012. Knowledge, Desire, and Power in Global Politics: Western Representations of China's Rise. Cheltenham, UK: Edward Elgar.

Pang Zhongying. 2004. "China as a Normal State? Understanding China's Unfinished Transformation from a State Socialization Perspective." Journal of East Asian Affairs, vol. 18, no. 2 (Fall/Winter), pp. 340-369.

Pempel, T. J. 2010. "More Pax, Less Americana in Asia." International Relations of the Asia-Pacific, vol. 10, no. 3 (December), pp. 465490. 
$\mathrm{Pu}$, Xiaoyu. 2012. "Socialisation as a Two-Way Process: Emerging Powers and the Diffusion of International Norms." Chinese Journal of International Politics, vol. 5, no. 4 (Winter), pp. 341-367.

Qin, Yaqing, and Ling Wei. 2008. "Structures, Processes, and the Socialization of Power: East Asian Community-Building and the Rise of China." In Robert S. Ross and Zhu Feng, eds., China's Ascent: Power, Security, and the Future of International Relations. Ithaca, NY: Cornell University Press, pp. 115-138.

Rose, Gideon. 1998. "Neoclassical Realism and Theories of Foreign Policy." World Politics, vol. 51, no. 1 (October), pp. 144-172.

Ross, Robert S. 1999. "The Geography of the Peace: East Asia in the Twenty-First Century.” International Security, vol. 23, no. 4 (Spring), pp. 81-118.

Rothgeb, John M. 1994. Defining Power: Influence and Force in the Contemporary International System. London: St. Martin's Press.

Roy, Denny. 1994. "Hegemon on the Horizon? China's Threat to East Asian Security." International Security, vol. 19, no. 1 (Summer), pp. 149-168.

Samuels, Richard J. 2007. Securing Japan: Tokyo's Grand Strategy and the Future of East Asia. Ithaca, NY: Cornell University Press.

Schmidt, Brian. 2007. "Realist Conceptions of Power." In Felix Berenskoetter and M. J. Williams, eds., Power in World Politics. London: Routledge, pp. 43-63.

Schweller, Randall L., and Xiaoyu Pu. 2011. “After Unipolarity: China's Visions of International Order in an Era of US Decline." International Security, vol. 36, no. 1 (Summer), pp. 41-72.

Sending, Ole Jacob, and Iver B. Neumann. 2006. "Governance to Governmentality: Analyzing NGOs, States, and Power." International Studies Quarterly, vol. 50, no. 3 (September), pp. 651-672.

Shambaugh, David. 2004/05. "China Engages Asia: Reshaping the Regional Order.” International Security, vol. 29, no. 3 (Winter), pp. 64-99.

Shirk, Susan L. 2007. China: Fragile Superpower. Oxford: Oxford University Press.

Suzuki, Shogo. 2005. “Japan's Socialization into Janus-Faced European International Society." European Journal of International Relations, vol. 11 , no. 1 , pp. $137-164$.

_ 2008. "Seeking 'Legitimate' Great Power Status in Post-Cold War International Society: China's and Japan's Participation in UNPKO." International Relations, vol. 22, no. 1, pp. 45-63.

Tammen, Ronald L., and Jacek Kugler. 2006. "Power Transition and ChinaUS Conflicts." Chinese Journal of International Politics, vol. 1, no. 1, pp. 35-55.

Taniguchi Makoto. 2004. "Higashi Ajia kyōdōtai: Keizai tōgō no yukue to Nihon" [East Asian Community: Japan and the outcome of economic integration]. Tokyo: Iwanami.

Turner, Oliver. 2014a. "The US Pivot to the Asia Pacific." In Inderjeet Parmar, Linda B. Miller, and Mark Ledwidge, eds., Obama and the World: New Directions in US Foreign Policy. London: Routledge, pp. 219-230. 
2014b. American Images of China: Identity, Power, Policy. London: Routledge.

Vogel, Ezra F. 1979. Japan as Number One: Lessons for America. Cambridge, MA: Harvard University Press.

Waltz, Kenneth N. 1979. Theory of International Politics. New York: McGraw-Hill.

- 2000. "Structural Realism After the Cold War." International Security, vol. 25, no. 1 (Summer), pp. 5-41.

White, Hugh. 2012. The China Choice: Why America Should Share Power. Collingwood, Australia: Black Inc.

Wohlforth, William C. 1993. The Elusive Balance: Power and Perceptions During the Cold War. Ithaca, NY: Cornell University Press.

Yan Xuetong. 2006. "The Rise of China and Its Power Status." Chinese Journal of International Politics, vol. 1, no. 1, pp. 5-33.

Zhao, Quansheng. 2007. "Managed Great Power Relations: Do We See 'One-Up and One-Down'?” Journal of Strategic Studies, vol. 30, nos. 4-5 (August-October), pp. 609-637. 
Reproduced with permission of the copyright owner. Further reproduction prohibited without permission. 